\title{
SLC28A2 wt Allele
}

National Cancer Institute

\section{Source}

National Cancer Institute. SLC28A2 wt Allele. NCI Thesaurus. Code C113319.

Human SLC28A2 wild-type allele is located in the vicinity of $15 q 15$ and is approximately 24 $\mathrm{kb}$ in length. This allele, which encodes sodium/nucleoside cotransporter 2 protein, plays a role in the transport of purine nucleosides. 